\title{
Pathogen inferred to have dispersed thousands of kilometres at sea, infecting multiple keystone kelp species
}

\author{
Abigail L. Mabey ${ }^{1,2}$ (D) Elahe Parvizi ${ }^{3}$ (1) $\cdot$ Ceridwen I. Fraser ${ }^{3}$ (i)
}

Received: 25 November 2020 / Accepted: 19 February 2021 / Published online: 18 March 2021

(c) The Author(s) 2021

\begin{abstract}
Protistan pathogens have been found to infect populations of some large brown macroalgae. Infection could reduce the ability of macroalgae to withstand hydrodynamic pressures through weakening tissues and reducing flexibility. Widespread mortality of macroalgae if disease outbreaks were to occur could have important flow-on consequences for biodiversity and ecosystem function. Recent discoveries of the protistan pathogen Maullinia infecting the ecologically keystone southern bull kelp Durvillaea in Chile, Australia, and on Marion Island, raise the possibility that this pathogen is dispersing across ocean basins with buoyant hosts. To determine whether Maullinia also infects southern bull kelp in New Zealand, samples of gall-like tissue from Durvillaea antarctica, D. poha, and D. willana were collected from intertidal sites, and genetic analyses (sequencing of partial 18S rRNA) carried out. Maullinia infections were detected in all three species of Durvillaea. Phylogenetic analyses show a close relationship of New Zealand Maullinia to M. braseltonii previously detected in Chile and on Marion Island. Based on its genetic similarity to distant lineages and its presence on buoyant hosts that have been shown to drift long distances at seas, we infer that Maullinia has dispersed across the Southern Ocean through rafting of infected bull kelp. Understanding the capacity of pathogens to disperse across oceans is critical part of forecasting and managing ecosystem responses to environmental change.
\end{abstract}

\section{Introduction}

Pathogens can have a major effect on ecosystem processes, and can exercise controls on populations through reducing the biomass and abundance of species, influencing the phenotypes of hosts, and altering species interactions (Price et al. 1986; Harvell et al. 2002; Groner et al. 2016; Fischhoff et al. 2020). Despite this, implications of disease have been understudied by ecologists relative to other biotic interactions (Campbell et al. 2014).

Responsible Editor: K. Bischof.

Reviewers:undisclosed experts.

Abigail L. Mabey

A.L.Mabey@ soton.ac.uk

1 School of Ocean and Earth Science, National Oceanography Centre Southampton, University of Southampton, Southampton SO14 3ZH, UK

2 Biological Sciences, University of Southampton, Southampton SO17 1BJ, UK

3 Department of Marine Science, University of Otago, PO Box 56, Dunedin 9054, New Zealand
Parasites and pathogens are common in macroalgae, and whilst not all diseases will go on to disrupt ecosystem processes (Harley et al. 2012; Groner et al. 2016), when foundational species such as macroalgae are disrupted, it can have disproportionate impacts which cascade through trophic levels and alter habitat functioning (Harvell et al. 1999; Schiel 2006; Cohen et al. 2018). Such impacts are of particular concern in marine ecosystems where high levels of connectedness can facilitate rapid spread of pathogens over large distances (McCallum et al. 2003). Dispersal to new areas is likely to result in novel contact between the pathogen and the host, which could have serious consequences if the hosts have little or no resistance to the unfamiliar pathogen (Harvell et al. 2002; Cohen et al. 2018). Climate change is predicted to exacerbate the problem, through expanding pathogen ranges and making hosts more susceptible to infection through increased stress (Campbell et al. 2011; Kumar et al. 2016; Cohen et al. 2018). Early monitoring in combination with long-term data collection, including assessing disease prevalence, is essential to enable us to effectively respond to and manage disease outbreaks through understanding how host-pathogen interactions vary with climate 
change and extreme events (Harvell et al. 2002; Burge et al. 2014; Groner et al. 2016).

Maullinia is an intracellular, protistan pathogen genus first described just 20 years ago when it was found on filamentous brown algae in Chile (Maier et al. 2000). Thus far, relatively little research has been carried out to understand the ecology of this pathogen, and the potential impact it could have on macroalgal communities. Maullinia has been found across the Southern Hemisphere, in Chile, the Falkland Islands, sub-Antarctic islands, and Australia on both filamentous brown algae and on southern bull kelp species (Maier et al. 2000; Goecke et al. 2012; Blake et al. 2017; Murúa et al. 2017). Maullinia can cause yellowish galls, between 0.5 and $4.0 \mathrm{~cm}$ in size (Goecke et al. 2012; Blake et al. 2017; Murúa et al. 2017) to form on southern bull kelp blades. Additionally, M. ectocarpii has been found to infect gametophytes of kelp species Macrocystis and Desmarestia, which could disrupt the life cycle of these keystone kelp species, particularly in a commercial context (Maier et al. 2000). Southern bull kelp (Durvillaea) are large and ecologically important keystone species occupying intertidal and shallow subtidal zones (Fraser et al. 2020). To withstand the wave forces in these dynamic environments, Durvillaea species are highly flexible and strong (Kelly and Brown 2000). The formation of galls on the blades of Durvillaea could reduce the kelps' elasticity and flexibility, which could affect their health and survival (Goecke et al. 2012). Durvillaea species provide refuge for understory species, and act as a substratum for various epiphyte taxa (Taylor and Schiel 2005). Some species host diverse invertebrate fauna in their holdfasts, many of which depend on the macroalgae for food and habitat. Additionally, stranded Durvillaea detritus is an important food source for marine and terrestrial fauna (Jaramillo et al. 2006; Dufour et al. 2012). These foundational species are essential for the healthy functioning of intertidal ecosystems in the cool-temperate Southern Hemisphere, as well as having important economic and social roles in aquaculture (Murúa et al. 2017).

The Durvillaea genus includes three buoyant species, whose thalli contain a gas-filled honeycomb structure (Fraser et al. 2020). This trait has promoted long-distance dispersal of Durvillaea species such as D. antarctica, which has been found washed up on coasts thousands-and even tens of thousands - of kilometres away from known source populations (Moore and Cribb 1952; Fraser et al. 2011, 2018; Waters et al. 2018). These buoyant species are an important mechanism for the dispersal of coastal taxa, as they can transport other organisms with them, such as invertebrates, other algal species, and marine parasites (Thiel and Gutow 2005a, b; Fraser and Waters 2013). Emerging data showing a wide distribution of Maullinia across the Southern Hemisphere suggest that Maullinia might also disperse with these buoyant hosts. Research into the dispersal of
Maullinia without host organisms is limited. The life cycle of Maullinia does include resting spores (Maier et al. 2000; Parodi et al. 2010; Goecke et al. 2012; Murúa et al. 2017), which may be able to survive for periods without the host (Neuhauser et al. 2011), but the extent of this is currently unknown, as is its ability to disperse on artificial substrata. Additionally, M. ectocarpii has been found to form cysts on sporangia of filamentous seaweeds (Maier et al. 2000), but there are no records of $M$. ectocarpii forming cysts on artificial substrata and dispersing in this way. Blake et al. (2017) found evidence that a Maullinia lineage on buoyant Durvillaea in Chile was indistinguishable from a lineage on buoyant Durvillaea on the distant sub-Antarctic Marion Island in the Indian Ocean, and that a lineage found on the filamentous alga Ectocarpus in Chile was closely related to lineages detected on non-buoyant Durvillaea in Australia, suggesting long-distance dispersal had recently occurred. Additionally, Maullinia prevalence differed with latitude, suggesting that environmental parameters affect the susceptibility of Durvillaea to infection (Blake et al. 2017).

New Zealand is a centre of diversity for southern bull kelp species, with several buoyant and non-buoyant species found in the region (Fraser et al. 2020). To date, however, Maullinia infections have not been recorded from New Zealand bull kelp populations. Given the evidence for long-distance dispersal of these marine pathogens around the Southern Hemisphere, we hypothesised that Maullinia would also be present in New Zealand. We tested this hypothesis using targeted sampling of tissue from three sympatric but ecologically and morphologically distinct Durvillaea species in New Zealand (the buoyant species $D$. antarctica and $D$. poha, and the non-buoyant species $D$. willana), followed by genetic sequencing to test for presence of the pathogen.

\section{Methodology}

\section{Sampling}

Sampling was conducted at eight sites on the south-east coast of the South Island, New Zealand, and one site on the North Island near Wellington (Fig. 1). The majority of the sampling occurred between February and March 2020 with the exception of Taieri Beach and Island Bay which were sampled in March and December 2019, respectively, in the intertidal zone of rock platforms (Appendix S1). Durvillaea poha, D. antarctica and $D$. willana were visually examined for signs of any pathogenic infection such as lesions or galls. 123 tissue samples from individual Durvillaea species were collected from infected kelp to test the presence of Maullinia via genetic analysis. Samples were either air-dried on a clean paper towel after initial desiccation in high-concentration 
Fig. 1 Sites in New Zealand where field sampling was conducted in $\mathbf{b}$ one site in the North Island and $\mathbf{c}$ eight sites in the South Island. Stars in panel (c) represent sites where Maullinia was confirmed from Durvillaea hosts
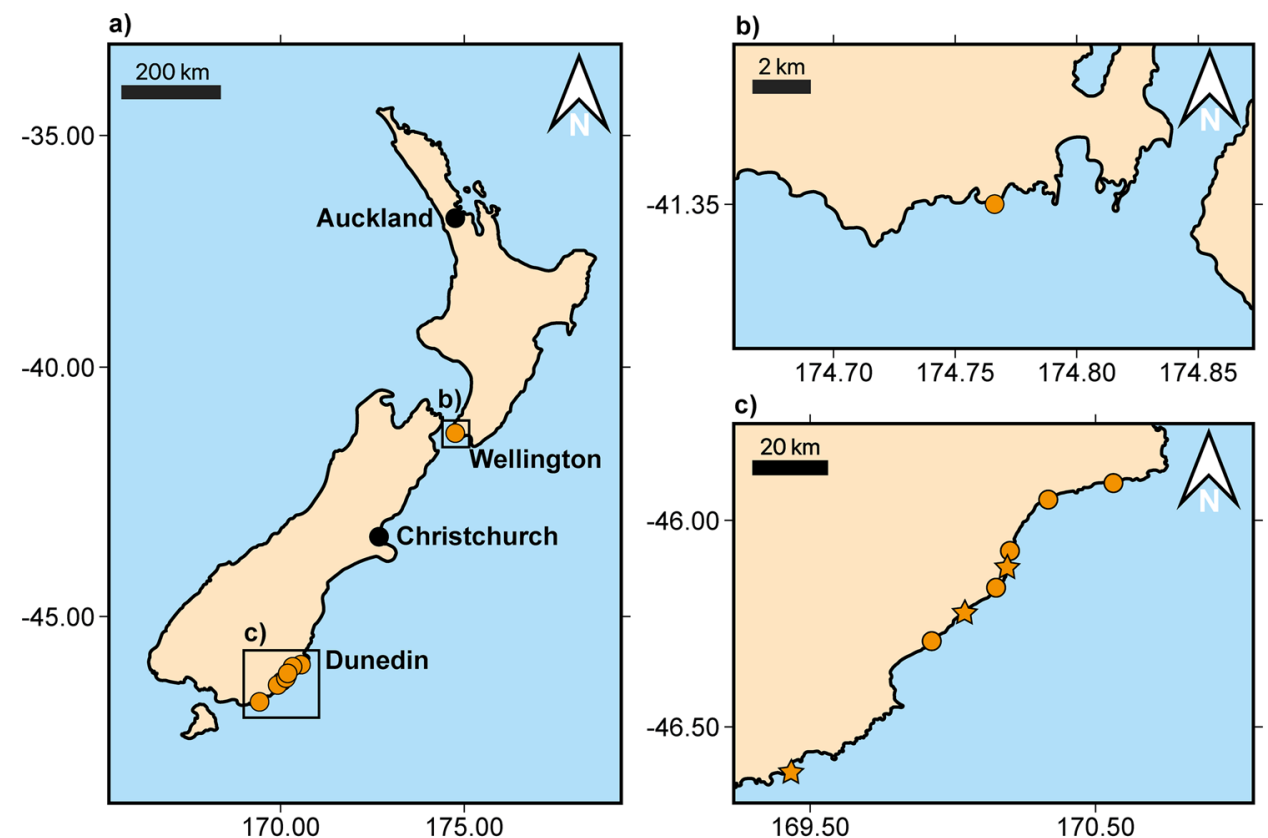

ethanol, or air-dried in an oven at $50{ }^{\circ} \mathrm{C}$ for several hours, and then stored over silica gel beads.

\section{Genetic analysis}

All 123 samples had DNA extracted and underwent PCR. DNA extraction and PCR followed methods described in Blake et al. (2017). Small $(<2 \mathrm{~mm})$ pieces of infected, dried kelp tissue were excised using a scalpel sterilized with bleach and ethanol, and DNA was extracted using the standard Chelex ${ }^{\circledR}$ protocol (Walsh et al. 1991). Extractions were diluted 1:100 in MilliQ water to reduce the likelihood of alginates inhibiting PCR. PCR amplification was conducted in a $20 \mu$ solution, comprising $12.9 \mu \mathrm{l}$ of MilliQ water, $0.5 \mu \mathrm{M}$ each of forward and reverse primer (Mau2F and Mau9R: Goecke et al. 2012), $4 \mu \mathrm{l}$ of MyTaq Red Reaction buffer, $0.1 \mu \mathrm{l}$ of MyTaq Red DNA Polymerase (Bioline), and $1 \mu \mathrm{l}$ of the diluted DNA extraction. The primers amplified part of the $18 \mathrm{~S}$ nuclear ribosomal gene. PCRs were run in an Eppendorf Mastercycler using a touchdown PCR protocol: $96^{\circ} \mathrm{C}$ for 4 min initial denaturation, followed by two cycles of $96^{\circ} \mathrm{C}$ for $25 \mathrm{~s}, 65^{\circ} \mathrm{C}$ for $25 \mathrm{~s}$ and $72{ }^{\circ} \mathrm{C}$ for $1.5 \mathrm{~min}$ followed by two cycles each with a primer annealing temperature of $60^{\circ} \mathrm{C}$ and $58^{\circ} \mathrm{C}$ and finally 30 cycles with a primer annealing temperature of $54^{\circ} \mathrm{C}$ and a final slope of $72^{\circ} \mathrm{C}$ for 10 min (Goecke et al. 2012). PCR products ( $1200 \mathrm{bp}$ in size) were purified using gel purification via a MEGAquick-spin ${ }^{\mathrm{TM}}$ plus fragment DNA purification kit (iNtRON). Some samples also showed amplification of a smaller fragment $(\sim 300 \mathrm{bp})$; sequencing revealed that these amplicons were from the host (BLAST results showed close match to a part of the $18 \mathrm{~S}$ marker amplified from Durvillaea), suggesting that the primers can sometimes anneal to New
Zealand bull kelp DNA. By gel purifying amplicons, we were able to target the pathogen rather than the host. For samples where Maullinia sequences were confirmed, COI sequences of the host were subsequently obtained following methods in Fraser et al. (2009) to verify host identification, as $D$. poha and $D$. antarctica can sometimes be misidentified in the field. Sequencing was carried out using the forward primer by the University of Otago's Genetic Analysis Services (Otago, New Zealand), using an Applied Biosystems 3730xl capillary sequencer (Thermo Fisher Scientific).

\section{Phylogenetic analysis}

Sequences were aligned, and ambiguities assessed by eye using Geneious Prime version 2020.1.1 (Kearse et al. 2012). Sequences were trimmed to 764 bases to remove poorquality sequence tails. Original sequences from Blake et al. 2017, and published sequences from known Maullinia species (M. braseltonii: GenBank Accession JX163857, and M. ectocarpii, Accession AF405547) were aligned with new sequences from this study. A mid-point rooted ML tree was built using PhyML (Guindon et al. 2010) via a TRN + I model (best model as assessed by the AICc of jModeltest2: Darriba et al. 2012), with the proportion of invariable sites set at 0.809 .

\section{Results and discussion}

The protistan pathogen Maullinia was confirmed from three bull kelp species in New Zealand: the buoyant $D$. antarctica (one individual) and D. poha (three individuals), and the 
solid-bladed D. willana (one individual) (Table 1). Maullinia was detected at three intertidal sites on the South Island across a coastal distance of $>70 \mathrm{~km}$ (Fig. 1) suggesting the pathogen might be widespread, albeit probably at low prevalence, in southern New Zealand. Two sequences of Maullinia were detected. The first was detected from one individual of $D$. willana, a non-buoyant bull kelp species, and was identical to the most common sequence of M. braseltonii detected from buoyant bull kelp in Chile by Blake et al. (2017), lineage MC1 (GenBank Accession MF872446) (Fig. 2). The second sequence was detected from one individual of $D$. antarctica and three individuals of D. poha - the two buoyant hosts-and were identical across all sites and samples to each other, but the sequence had not been previously detected elsewhere (GenBank Accession MW131091). This lineage is most likely also $M$. braseltonii, as it differed from the other $D$. willana-associated sequence at only five out of 764 nucleotide sites $(<1 \%$; four transitions and two transversions). Both sequences found in this study were highly similar to sequences of $M$. braseltonii detected from buoyant species $D$. incurvata (recently split from $D$. antarctica (Fraser et al. 2020)) in Chile, and D. antarctica in the sub-Antarctic (Blake et al. 2017). That two lineages were detected could indicate multiple past introductions, or perhaps evolution of the pathogen driven by different host tissue types (buoyant, inflated blades versus non-buoyant, solid blades); a larger scale study could, in future, aim to test such hypotheses.

The discovery of $M$. braseltonii on bull kelp in New Zealand and its genetic similarity to geographically distant lineages suggests that $M$. braseltonii could have arrived through long-distance rafting of infected, buoyant kelp, either dispersing from Chile or sub-Antarctic islands to New Zealand, or vice versa. Further sampling could help to clarify the direction of travel. Our finding supports previous inferences of long-distance dispersal of marine pathogens via rafting with buoyant macroalgae (Fraser and Waters 2013; Blake et al. 2017). Blake et al. (2017) found M. ectocarpii in Australia on bull kelp taxa D. potatorum and $D$. amatheiae, so we might have expected to find $M$. ectocarpii in New Zealand (geographically relatively close to Australia), but these solid-bladed Durvillaea species are non-buoyant and thus have limited dispersal opportunities (Fraser et al. 2020; Hay 2020). In contrast, M. braseltonii-which as we show here can infect both buoyant and

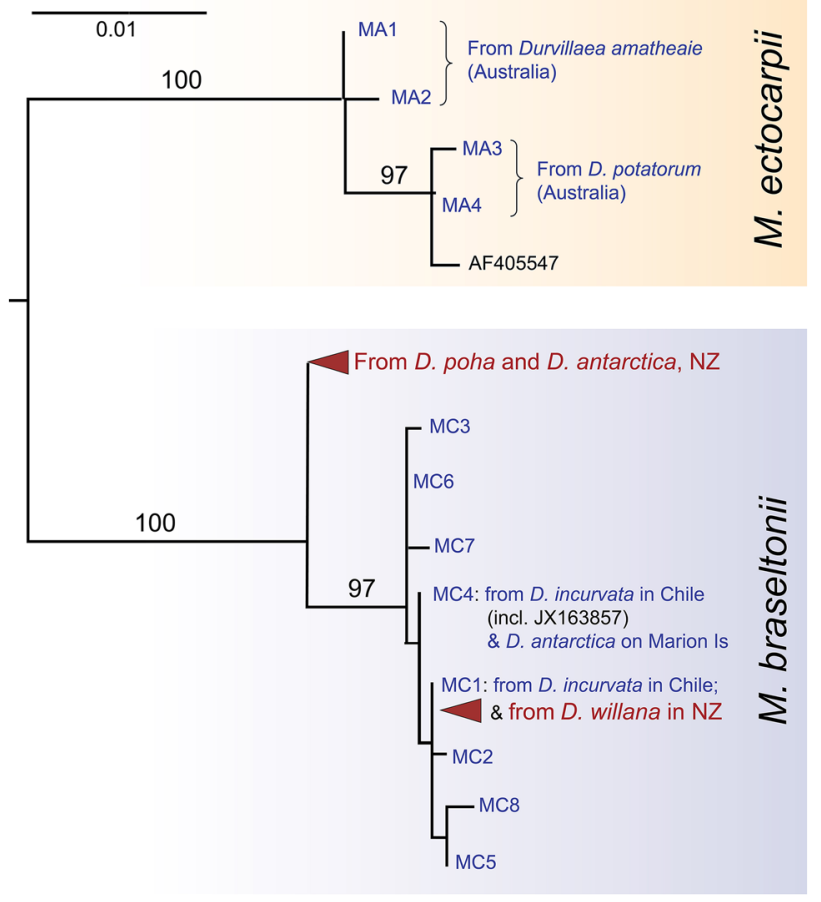

Fig. 2 Maximum likelihood phylogeny of published and new Maullinia partial $18 \mathrm{~S}$ data. The samples from New Zealand (this study) group with previously detected sequences from southern bull kelp from Chile and the sub-Antarctic. Blue text indicates data from Blake et al. (2017) (code MA refers to Maullinia detected in Australia, and code $\mathrm{MC}$ refers to strains collected from Chile, in that study), and red text indicates sequences from this study. The phylogeny is mid-pointrooted, with bootstrap values $>90 \%$ shown

non-buoyant Durvillaea-has now been shown to have a wide geographic range, infecting bull kelp in Chile, Marion Island (sub-Antarctic Indian Ocean) and New Zealand-locations separated by thousands of kilometres of ocean. Maullinia braseltonii might also be a more generalist pathogen than $M$. ectocarpii, as the same strain of $M$. braseltonii was found to infect both $D$. antarctica and $D$. poha. In contrast, strains of $M$. ectocarpii appear to be host specific in Australia (Blake et al. 2017). The capacity of the pathogen to infect several host species, including both buoyant and non-buoyant taxa in addition to filamentous alga previously found to be infected by M. ectocarpii (Maier et al. 2000), shows that Maullinia is a versatile and generalist pathogen.
Table 1 Maullinia sequences and host Durvillaea species with associated GenBank accession numbers and site locations

\begin{tabular}{lllll}
\hline Maullinia sp. & Host Durvillaea sp. & $\begin{array}{l}\text { GenBank acces- } \\
\text { sion number }\end{array}$ & $\begin{array}{l}\text { Number of con- } \\
\text { firmed infections }\end{array}$ & Sample site \\
\hline M. braseltonii & D. willana & MF872446 & 1 & Akatore \\
M. braseltonii & D. antarctica & MW131091 & 4 & $\begin{array}{c}\text { Toko Mouth } \\
\text { and Tautuku }\end{array}$ \\
& D. poha & & & Peninsula \\
\end{tabular}


From previous reports of Maullinia infection of bull kelp, we expected to find yellowish galls to indicate the pathogen's presence (Goecke et al. 2012; Blake et al. 2017). None of the bull kelp populations surveyed, however, showed obvious, large galls—instead showing only minor blemishes on host tissue-suggesting that galls are not always indicative of Maullinia infections. There might, however, be some seasonality in gall development, or environmental factors that influence the prevalence and manifestation of infections (Schade et al. 2016; Ford et al. 2018; Honjo et al. 2020). With the potential of disease outbreaks to have major impacts on population health and viability, further research is urgently needed to better understand the characteristics of this relatively newly discovered (Goecke et al. 2012), but apparently highly dispersive (Blake et al. 2017; this study) kelp pathogen.

Maullinia prevalence on bull kelp hosts has been found to vary with latitude and the associated environmental parameters (Blake et al. 2017). Infection prevalence increased towards higher latitudes in both Chile and Australia, which could be due to increased population density in southern parts of Durvillaea's range, or it could be that the Maullinia pathogen is more prevalent in colder waters (Blake et al. 2017), which may mean that increased temperatures could counteract the virulence of this pathogen (Blake et al. 2017). However this could be offset by physiological stresses caused by higher temperatures increasing organisms' susceptibility to disease (Case et al. 2011; Campbell et al. 2011; Beattie et al. 2018; Thomsen et al. 2019). Predicting how environmental change will affect the prevalence and impacts of Maullinia on Durvillaea is, therefore, currently difficult. Durvillaea species comprise a large proportion of the macroalgae biomass in coastal ecosystems in New Zealand (Thomsen et al. 2019; Hay 2020) and it would be devastating for nearshore marine communities if a disease outbreak were to significantly reduce the biomass of these species (Taylor and Schiel 2005; Jaramillo et al. 2006; Dufour et al. 2012; Murúa et al. 2017). Previous mortality events of Durvillaea have led to the increased spread of the highly invasive kelp Undaria pinnatifida (Thomsen et al. 2019), and the replacement of Durvillaea with this species would change the character and functioning of the ecosystem (Stuart 2004; Russell et al. 2008).

Understanding the controls of pathogen distributions is essential for monitoring and managing future disease outbreaks. Further assessment of macroalgal populations in New Zealand and elsewhere will be important to determine the virulence and potential risks this pathogen poses for coastal communities.

Supplementary Information The online version contains supplementary material available at https://doi.org/10.1007/s00227-021-03853-8.
Acknowledgements We thank Dave Craw, Felix Vaux and Graham Wallis for assistance in the field, Aled D. Evans for assistance with creation of the maps, and Jane A. Catford for facilitating this collaboration. CIF was supported by a Rutherford Discovery Fellowship from the Royal Society of New Zealand (RDF-UOO1803). AM was supported by the Natural Environmental Research Council [Grant number NE/L002531/1] and a School of Biological Sciences Studentship at the University of Southampton. We would also like to thank the reviewers for their constructive feedback of the manuscript.

Data availability The novel sequence detected in this study has been made publicly available by deposition in GenBank, Accession MW131091.

\section{Declarations}

Conflict of interest The authors declare that they have no conflict of interest.

Ethical approval All applicable international, national and institutional guidelines for sampling of organisms for the study have been followed.

Open Access This article is licensed under a Creative Commons Attribution 4.0 International License, which permits use, sharing, adaptation, distribution and reproduction in any medium or format, as long as you give appropriate credit to the original author(s) and the source, provide a link to the Creative Commons licence, and indicate if changes were made. The images or other third party material in this article are included in the article's Creative Commons licence, unless indicated otherwise in a credit line to the material. If material is not included in the article's Creative Commons licence and your intended use is not permitted by statutory regulation or exceeds the permitted use, you will need to obtain permission directly from the copyright holder. To view a copy of this licence, visit http://creativecommons.org/licenses/by/4.0/.

\section{References}

Beattie DT, Lachnit T, Dinsdale EA, Thomas T, Steinberg PD (2018) Novel ssDNA viruses detected in the virome of bleached, habitatforming kelp Ecklonia radiata. Front Mar Sci 4:441. https://doi. org/10.3389/fmars.2017.00441

Blake C, Thiel M, López B, Fraser C (2017) Gall-forming protistan parasites infect southern bull kelp across the Southern Ocean, with prevalence increasing to the south. Mar Ecol Prog Ser 583:95106. https://doi.org/10.3354/meps12346

Burge CA, MarkEakin C, Friedman CS, Froelich B, Hershberger PK, Hofmann EE, Petes LE, Prager KC, Weil E, Willis BL, Ford SE, Harvell CD (2014) Climate change influences on marine infectious diseases: implications for management and society. Annu Rev Mar Sci. https://doi.org/10.1146/annurev-marine-010213-135029

Campbell AH, Harder T, Nielsen S, Kjelleberg S, Steinberg PD (2011) Climate change and disease: bleaching of a chemically defended seaweed. Glob Chang Biol 17:2958-2970. https://doi.org/10. 1111/j.1365-2486.2011.02456.x

Campbell AH, Vergés A, Steinberg PD (2014) Demographic consequences of disease in a habitat-forming seaweed and impacts on interactions between natural enemies. Ecology 95:142-152. https://doi.org/10.1890/13-0213.1

Case RJ, Longford SR, Campbell AH, Low A, Tujula N, Steinberg PD, Kjelleberg S (2011) Temperature induced bacterial virulence and bleaching disease in a chemically defended marine macroalga. 
Environ Microbiol 13:529-537. https://doi.org/10.1111/j.14622920.2010.02356.x

Cohen R, James C, Lee A, Martinelli M, Muraoka W, Ortega M, Sadowski R, Starkey L, Szesciorka A, Timko S, Weiss E, Franks P (2018) Marine host-pathogen dynamics: influences of global climate change. Oceanography 31:182-193. https://doi.org/10. 5670/oceanog.2018.201

Darriba D, Taboada GL, Doallo R, Posada D (2012) jModelTest 2: more models, new heuristics and parallel computing. Nat Meth 9:772-772. https://doi.org/10.1038/nmeth.2109

Dufour C, Probert P, Savage C (2012) Macrofaunal colonisation of stranded Durvillaea antarctica on a southern New Zealand exposed sandy beach. NZ J Mar Freshw Res 46:369-383. https://doi.org/10.1080/00288330.2012.676557

Fischhoff IR, Huang T, Hamilton SK, Han BA, LaDeau SL, Ostfeld RS, Rosi EJ, Solomon CT (2020) Parasite and pathogen effects on ecosystem processes: a quantitative review. Ecosphere 11:1-12. https://doi.org/10.1002/ecs2.3057

Ford SE, Stokes NA, Alcox KA, Kraus BSF, Barber RD, Carnegie RB, Burreson EM (2018) Investigating the life cycle of Haplosporidium Nelsoni (Msx): a review. J Shellfish Res 37:679-693. https://doi.org/10.2983/035.037.0402

Fraser CI, Hay CH, Spencer HG, Waters JM (2009) Genetic and morphological analyses of the southern bull kelp Durvillaea antarctica (Phaeophyceae: Durvillaeales) in New Zealand reveal cryptic species. J Phycol 45:436-443

Fraser CI, Waters JM (2013) Algal parasite Herpodiscus durvillaeae (Phaeophyceae: Sphacelariales) inferred to have traversed the Pacific Ocean with its buoyant host. J Phycol 49:202-206. https://doi.org/10.1111/jpy.12017

Fraser CI, Nikula R, Waters JM (2011) Oceanic rafting by a coastal community. Proc R Soc B 278:649-655. https://doi.org/10. 1098/rspb.2010.1117

Fraser CI, Morrison AK, McC Hogg A, Macaya EC, van Sebille E, Ryan PG, Padovan A, Jack C, Valdivia N, Waters JM (2018) Antarctica's ecological isolation will be broken by storm-driven dispersal and warming. Nat Clim Change 8:704-708. https:// doi.org/10.1038/s41558-018-0209-7

Fraser CI, Velásquez M, Nelson WA, Macaya EC, Hay CH (2020) The biogeographic importance of buoyancy in macroalgae: a case study of the southern bull-kelp genus Durvillaea (Phaeophyceae), including descriptions of two new species. J Phycol 56:23-36. https://doi.org/10.1111/jpy.12939

Goecke F, Wiese J, Núñez A, Labes A, Imhoff JF, Neuhauser S (2012) A novel phytomyxean parasite associated with galls on the bull-kelp Durvillaea antarctica (Chamisso) Hariot. PLoS ONE 7:e45358. https://doi.org/10.1371/journal.pone.0045358

Groner ML, Maynard J, Breyta R, Carnegie RB, Dobson A, Friedman CS, Froelich B, Garren M, Gulland FMD, Heron SF, Noble RT, Revie CW, Shields JD, Vanderstichel R, Weil E, WyllieEcheverria S, Harvell CD (2016) Managing marine disease emergencies in an era of rapid change. Philos Trans R Soc B 371:20150364. https://doi.org/10.1098/rstb.2015.0364

Guindon S, Dufayard J-F, Lefort V, Anisimova M, Hordijk W, Gascuel O (2010) New algorithms and methods to estimate maximum-likelihood phylogenies: assessing the performance of PhyML 3.0. Syst Biol 59:307-321. https://doi.org/10.1093/ sysbio/syq010

Harley CDG, Anderson KM, Demes KW, Jorve JP, Kordas RL, Coyle TA, Graham MH (2012) Effects of climate change on global seaweed communities. J Phycol 48:1064-1078. https://doi.org/10. 1111/j.1529-8817.2012.01224.x

Harvell CD, Kim K, Burkholder JM, Colwell RR, Epstein PR, Grimes DJ, Hofmann EE, Lipp EK, Osterhaus ADME, Overstreet RM, Porter JW, Smith GW, Vasta GR (1999) Emerging marine diseases-climate links and anthropogenic factors. Science 285:1505-1510. https://doi.org/10.1126/science.285.5433.1505

Harvell CD, Mitchell CE, Ward JR, Altizer S, Dobson AP, Ostfeld RS, Samuel MD (2002) Climate warming and disease risks for terrestria and marine biota. Science 296:2158-2162. https://doi. org/10.1126/science.1063699

Hay CH (2020) Seashore uplift and the distribution of the bull kelp Durvillaea willana Lindauer in New Zealand. NZ J Bot 58:94117. https://doi.org/10.1080/0028825X.2019.1679842

Honjo MN, Emura N, Kawagoe T, Sugisaka J, Kamitani M, Nagano AJ, Kudoh H (2020) Seasonality of interactions between a plant virus and its host during persistent infection in a natural environment. ISME J 14:506-518. https://doi.org/10.1038/s41396-019-0519-4

Jaramillo E, Huz RDL, Duarte C, Contreras H (2006) Algal wrack deposits and macroinfaunal arthropods on sandy beaches of the Chilean coast. Rev Chil de Hist Nat 79:337-351. https://doi.org/ 10.4067/S0716-078X2006000300006

Kearse M, Moir R, Wilson A, Stones-Havas S, Cheung M, Sturrock S, Buxton S, Cooper A, Markowitz S, Duran C, Thierer T, Ashton B, Meintjes P, Drummond A (2012) Geneious Basic: an integrated and extendable desktop software platform for the organization and analysis of sequence data. Bioinformatics 28:1647-1649. https:// doi.org/10.1093/bioinformatics/bts199

Kelly BJ, Brown MT (2000) Variations in the alginate content and composition of Durvillaea antarctica and D. willana from southern New Zealand. J Appl Phycol 12:317-324. https://doi.org/10. 1023/A:1008106723185

Kumar V, Zozaya-Valdes E, Kjelleberg S, Thomas T, Egan S (2016) Multiple opportunistic pathogens can cause a bleaching disease in the red seaweed Delisea pulchra. Environ Microbiol 18:39623975. https://doi.org/10.1111/1462-2920.13403

Maier I, Parodi E, Westermeier R, Müller DG (2000) Maullinia ectocarpii gen. et sp. nov. (Plasmodiophorea), an intracellular parasite in Ectocarpus siliculosus (Ectocarpales, Phaeophyceae) and other filamentous brown algae. Protist 151:225-238. https://doi.org/10. 1078/1434-4610-00021

McCallum H, Harvell D, Dobson A (2003) Rates of spread of marine pathogens. Ecol Lett 6:1062-1067. https://doi.org/10.1046/j.14610248.2003.00545.x

Moore LB, Cribb AB (1952) The brown alga Durvillea antarctica in Australian waters. Nature 169:1101-1102. https://doi.org/10. $1038 / 1691100 \mathrm{a} 0$

Murúa P, Goecke F, Westermeier R, van West P, Küpper FC, Neuhauser S (2017) Maullinia braseltonii sp. nov. (Rhizaria, Phytomyxea, Phagomyxida): a cyst-forming parasite of the bull kelp Durvillaea spp. (Stramenopila, Phaeophyceae, Fucales). Protist 168:468-480. https://doi.org/10.1016/j.protis.2017.07.001

Neuhauser S, Kirchmair M, Gleason FH (2011) Ecological roles of the parasitic phytomyxids (plasmodiophorids) in marine ecosystems-a review. Mar Freshw Res 62:365-371. https://doi.org/10. 1071/MF10282

Parodi ER, Cáceres EJ, Westermeier R, Müller DG (2010) Secondary zoospores in the algal endoparasite Maullinia ectocarpii (Plasmodiophoromycota). Biocell 34:45-52

Price PW, Westoby M, Rice B, Atsatt PR, Fritz RS, Thompson JN, Mobley K (1986) Parasite mediation in ecological interactions. Annu Rev Ecol System 17:487-505. https://doi.org/10.1146/annur ev.es.17.110186.002415

Russell LK, Hepburn CD, Hurd CL, Stuart MD (2008) The expanding range of Undaria pinnatifida in southern New Zealand: distribution, dispersal mechanisms and the invasion of wave-exposed environments. Biol Invasions 10:103-115. https://doi.org/10. 1007/s10530-007-9113-1

Schade FM, Raupach MJ, Mathias Wegner K (2016) Seasonal variation in parasite infection patterns of marine fish species from the Northern Wadden Sea in relation to interannual temperature 
fluctuations. J Sea Res 113:73-84. https://doi.org/10.1016/j. seares.2015.09.002

Schiel DR (2006) Rivets or bolts? when single species count in the function of temperate rocky reef communities. J Exp Mar Biol Ecol 338:233-252. https://doi.org/10.1016/j.jembe.2006.06.023

Stuart MD (2004) Review of research on Undaria pinnatifida in New Zealand and its potential impacts on the eastern coast of the South Island. Department of Conservation, Wellington

Taylor D, Schiel D (2005) Self-replacement and community modification by the southern bull kelp Durvillaea antarctica. Mar Ecol Prog Ser 288:87-102. https://doi.org/10.3354/meps288087

Thiel M, Gutow L (2005a) The ecology of rafting in the marine environment I The floating substrata. In: Gibson R, Atkinson R, Gordon J (eds) Oceanography and marine biology. CRC Press, Florida, pp 181-263

Thiel M, Gutow L (2005b) The ecology of rafting in the marine environment II The rafting organisms and community. In: Gibson R, Gordon J, Atkinson R (eds) Oceanography and marine biology. CRC Press, Florida, pp 279-418
Thomsen MS, Mondardini L, Alestra T, Gerrity S, Tait L, South PM, Lilley SA, Schiel DR (2019) Local extinction of bull kelp (Durvillaea spp.) due to a marine heatwave. Front Mar Sci 6:1-10. https://doi.org/10.3389/fmars.2019.00084

Walsh P, Metzger D, Higuchi R (1991) Chelex 100 as a medium for simple extraction of DNA for PCR-based typing from forensic material. Biotechniques 10:506-513. https://doi.org/10.2144/ 000114018

Waters JM, King TM, Fraser CI, Craw D (2018) Crossing the front: contrasting storm-forced dispersal dynamics revealed by biological, geological and genetic analysis of beach-cast kelp. J R Soc Interface 15:20180046. https://doi.org/10.1098/rsif.2018.0046

Publisher's Note Springer Nature remains neutral with regard to jurisdictional claims in published maps and institutional affiliations. 